\title{
Human health risk assessment of trace metals contamination in a tropical river
}

\author{
E. I. Uwah ${ }^{1,2 *}$, E. M. Edem ${ }^{1}$, I. E. Udosen ${ }^{3}$, E. D. Udosen ${ }^{1}$, O. M. Udoidiong ${ }^{4}$ and A. M. Essien ${ }^{5}$ \\ ${ }^{1}$ Department of Chemistry, University of Uyo, Uyo, Nigeria \\ ${ }^{2}$ International Centre for Energy and Environmental Sustainability Research (ICEESR), University of \\ Uyo, Uyo, Nigeria \\ ${ }^{3}$ Department of Zoology, Akwa Ibom State University, Ikot Akpaden, Nigeria \\ ${ }^{4}$ Department of Fisheries \& Aquatic Environmental Management, University of Uyo, Uyo, Nigeria \\ ${ }^{5}$ Department of Science Laboratory Technology, Akwa Ibom State Polytechnic, Ikot Ekpene, Nigeria \\ *Corresponding author, Email: emmanueliuwah@uniuyo.edu.ng, Tel: +2348028251882 \\ Received 12 August 2020; accepted 16 October 2020, published online 30 January 2021
}

\begin{abstract}
Levels of trace metals $(\mathrm{Cd}, \mathrm{Cr}, \mathrm{Cu}, \mathrm{Pb}$ and $\mathrm{Zn})$ were quantified in water, sediment and winkles (Pachymelania bryonensis and Pachymelania fusca mutans) in Akani Obio Uruan River, Nigeria during wet and dry seasons using standard procedures. Results revealed that mean levels $(\mathrm{mg} / \mathrm{l})$ of the metals in water ranged from 0.016 for $\mathrm{Cr}$ to 0.087 for $\mathrm{Cd}$ in wet season and 0.010 for $\mathrm{Cu}$ to 0.082 for $\mathrm{Zn}$ in dry season. In sediment, the metals levels $(\mathrm{mg} / \mathrm{kg}$ ) ranged from 0.002 for $\mathrm{Pb}$ to $0.161 \mathrm{for} \mathrm{Zn}$ in wet season and 0.001 for $\mathrm{Pb}$ to 0.438 for $\mathrm{Cu}$ in dry season. In winkles, the metals levels $(\mathrm{mg} / \mathrm{kg}$ ) ranged from 0.002 for $\mathrm{Pb}$ to 0.069 for $\mathrm{Cd}$ and for $\mathrm{Cu}$ in the wet season, and 0.001 for $\mathrm{Pb}$ to 0.058 for $\mathrm{Cd}$ and for $\mathrm{Cu}$ in the dry season. Estimated human health risk from each metal contamination due to consumption of the water, dermal absorption through swimming and consumption of winkles gave each of hazard quotient (HQ) and hazard index $(\mathrm{HI})$ values of less than one $(<1)$, indicating no risk since the levels of contamination in each case are not likely to cause any adverse health effects in humans.
\end{abstract}

Keywords: Health risks, assessment, trace metals, contamination, Akani Obio Uruan

\section{INTRODUCTION}

Rivers are of both ecological and economic significance to the society [1]. Rivers are quite vulnerable to pollution because they are naturally open and easily accessible, hence their being used substantially as dumps for agricultural, industrial, and municipal wastes [2, $3]$. The most common pathway by which aquatic systems receive wastes is through direct discharge of urban and industrial wastes. Experts estimate that urban and industrial wastes introduce up to one million different potential pollutants into aquatic systems [4]. The toxicity of the aquatic environment poses threat to man due to the fact that safe and suitable potable water supply for drinking and other uses are lacking especially in rural settlements in Nigeria. These make rural dwellers to depend on rivers, streams, natural ponds, lakes, shallow hand-dug wells and harvesting of rain water to meet their water needs [3]. Nevertheless, a body of water is not regarded as being polluted unless one or more contaminants have rendered it unsuitable for the purpose which it was meant to serve such as domestic, industrial, agricultural and recreational purposes. The issues of protection of water sources against faecal, agricultural and industrial contamination or pollution which is continually threatening the terrestrial and aquatic ecosystems due to increasing inputs of untreated wastes and chemical agents that are capable of causing damage to the environment are of great concern [5, 3]. Hazardous chemicals may become enriched and biomagnified through the food chain, posing risks to aquatic organisms. In addition, when fish and other sea animals from such waters are used for human consumption, there should be periodic monitoring to protect the health of those who consume such fish and animals [6].

Trace metals are the components of common environmental contaminants. Other contaminants include radionuclide, endocrine disrupting chemicals, toxic gases, plant nutrients and various oxygen consuming wastes [7]. The sources of these contaminants include agricultural chemicals such as fertilizers, pesticides, and herbicides, atmospheric 
emissions from industries and households, leachates from waste dumps, community sewage, treated and untreated industrial effluents [8]. Trace metals are commonly called heavy metals. Heavy metals are indeed known as trace metals because they are present at much lower concentration in water compared to major ions such as $\mathrm{SO}_{4}{ }^{2-}, \mathrm{PO}_{4}{ }^{3-}, \mathrm{NO}_{3}^{-}, \mathrm{NO}_{2}^{-}, \mathrm{Mg}^{2+}, \mathrm{Ca}^{2+}$ and $\mathrm{Cl}^{-}[9-11]$.

Trace metals are of particular concern due to their prevalent toxicity to aquatic organisms and their persistence in the environment [12,3]. Trace metals are non-biodegradable and undergo ecological cycle in which natural waters are the main pathways [13]. Trace metals in high levels in the environment, have been reported to cause neurological disorders, especially in the foetus and in children, which can lead to behavioural changes and impaired performance in intelligence quotient (IQ) test [14]. The level of trace metals in an aquatic environment depends on the amount of trace metal waste entering the water body. The more the waste entering the water, the higher the level found in the water. The trace metals which enter a water body will undergo sedimentation, dilution, dispersion, and then absorbed by the organisms living in the water and the trace metals which settle at the bottom will be stored in the sediment [15]. Therefore, the profile of trace contaminants in undisturbed sediment cores can be utilised to estimate the extent and history of pollution in aquatic environment [16].

Winkles are aquatic mollusks that are unsegmented, soft bodied and externally covered by hard calcareous shell that is segmented. The adults are benthic and their larvae are planktonic [17, 3]. Winkles are usually found on mud flats in the water. Usually they are about $6 \mathrm{~cm}$ in length, and dark gray in colour. Like mudskipper fish, winkles are also valuable commercially. Their collections and marketing form an important industry in the Niger Delta of Nigeria. The nutritive values of winkles compare favourably with those of domestic livestocks and fish [18]. Winkles such as Pachymelania bryonensis and Pachymelania fusca mutans are mollusks of high economic value in the Niger Delta of Nigeria. They are deposit feeders and bio- indicators of metals and hydrocarbon pollutions in the marine environment. Indeed winkles, like many aquatic organisms, have the ability to accumulate and bio-magnify contaminants like trace metals [3].

Data and information on the levels of trace metals in some rivers in the Niger Delta region of Nigeria are available. For example, Davies et al. [19] reported the levels of $\mathrm{Cr}, \mathrm{Pb}$ and $\mathrm{Cd}$ in water, periwinkle (T. fuscatus) and sediment from Elechi Creek. They noted that the metals levels were higher in sediment than in water and higher in periwinkle than in sediment. Similarly, Wokoma [20] in his study on trace metal burden in water, sediment and crab from Sombreiro River, reported that the levels of the investigated metals were higher in sediment than in water, with the levels ranging from $0.02 \pm 0.01$ to $340.6 \pm 106.21 \mathrm{mg} / \mathrm{kg}$ in sediment, and 0.01 to $0.99 \pm 0.104 \mathrm{mg} / \mathrm{l}$ in water. Also, Onwali et al. [21] investigated the level of $\mathrm{Pb}$ in periwinkle and sediment samples from the Eagle Island River in Port Harcourt and noted that the levels of $\mathrm{Pb}$ in the periwinkle and sediment were $0.91 \pm 0.54$ and $0.22 \pm 0.19 \mathrm{mg} / \mathrm{kg}$, respectively. Also, in a study carried out by Udousoro et al. [22] on bioaccumulation of trace elements in shellfish and their leachates from two coastal areas of Nigeria, it was noted that trace element levels varied between species of the periwinkles and that high levels of $\mathrm{Ni}, \mathrm{Cd}, \mathrm{Cu}$, and $\mathrm{Fe}$ were recorded in Pachymelania fusca mutans, while high levels of $\mathrm{Zn}$ and $\mathrm{Pb}$ were recorded in Tympanotonus fuscatus. Equally, in a study to evaluate the levels of trace metals in sediment from river Ethiope, Delta state, Nigeria, Osakwe and Peretiemo - Clarke [23] noted that the sources of the trace metals were mainly anthropogenic and that the levels of the metals in the investigated sediment were in the order: $\mathrm{Zn}>\mathrm{Pb}>\mathrm{Cu}>\mathrm{Mn}>\mathrm{N} \mathrm{I}>\mathrm{Cr}$. In their study on the distribution of lead in tissue of periwinkle (T. fuscatus and Pachymelania aurita) in upper Bonny River, Nigeria, Ideriah et al. [24] reported that the analysed periwinkle species contained low levels of $\mathrm{Pb}$. However, there are no reports of any form either on the levels or on human health risk assessment of trace metals contamination of Akani Obio Uruan River. 
This study therefore became necessary because anthropogenic activities over a period of time could lead to accumulation of toxic elements in the river thereby posing human health risks to the inhabitants of the area who fed on aquatic animals from the river and also used the river for recreational and domestic purposes. The expected results would provide adequate data on the levels of these elements in the river system thereby providing information on the degree of pollution of the river by the elements and uptake of the elements through the investigated media. Therefore, this study is aimed at investigating the levels of some trace metals $(\mathrm{Cd}, \mathrm{Cr}, \mathrm{Cu}, \mathrm{Pb}$ and $\mathrm{Zn}$ ) in water, sediment and two species of winkles (Pachymelania bryonensis and Pachymelania fusca mutans) from Akani Obio Uruan River in Nigeria's Niger Delta, as well as assessing the human health risks associated with the domestic usages of the water and consumption of the winkles from the river.

\section{MATERIALS AND METHODS}

Study area: The study was carried out at Akani Obio Uruan River (one of the rivers in the braided stretch of lower Cross River) in Uruan, Akwa Ibom State. The area is located on longitude $81^{\circ} 14 \mathrm{E}$ and latitude $50^{\circ} 87 \mathrm{~N}$ in south - south Nigeria. The river is situated downhill which makes it highly accessible to surface run-off water from the boat repair shops, human feaces, domestic wastes, open dump site wastes and agrochemical wastes from agricultural farmlands. The inhabitants of the area enjoy only one season: the dry season. The wet season often poses problems as the whole area is usually flooded. During the wet season tremendous run off from the thinly vegetated slopes often carry into the river a lot of wastes, resulting from all kinds of anthropogenic activities. Most of the inhabitants of the area depend on the river for their domestic needs, recreation and fishing.

Samples collection: Sampling was done between August and September 2018 for wet season and February and March 2019 for dry season. Water, sediment and two species of winkles (Pachymelania bryonensis and Pachymelania fusca mutans) were collected. Sampling was carried out at two (2) locations, namely: location one (1) for the upstream and location two (2) to represent the downstream. Three (3) water samples each of water from the upstream and downstream were randomly collected from three different points, making a total of 18 for each season. The water samples were collected in nitric acid pre-rinsed $1 \mathrm{~L}$ containers and $5 \mathrm{ml}$ of concentrated nitric acid added immediately to minimise chemisorption. Water collection was done by dipping each mouth of the container against the flow direction to avoid trapping air bubbles in the bottle. Sufficient air spaces were left in all the bottles to allow for expansion [25]. Sediment samples were collected alongside the water samples at a depth of about $25 \mathrm{~m}$ using Van Veen grab sampler at three different points and made into composite samples. The sediment samples collected were stored in $1 \mathrm{~L}$ plastic bottles. Winkles ( $P$. bryonensis and $P$. fusca mutans) samples were handpicked along the river bank, washed immediately with the river water to remove mud and algae. Collected samples were properly labeled and stored at $20^{\circ} \mathrm{C}$ prior to analyses.

Preparations of sediment and winkles samples: These were done by methods adopted by Wokoma [20] and Onwali et al. [21]. Sediment samples were air-dried, ground and sieved through a $2.00 \mathrm{~mm}$ mesh into fine form. For each of the finely ground sediment samples, $20 \mathrm{~g}$ were kept in an air-tight plastic bottle prior to digestion. The winkles were properly washed with distilled water to remove loosely held particles and the shells broken to remove the edible parts including the filaments which were washed and oven-dried at $60{ }^{\circ} \mathrm{C}$ for 5 days. The dried samples were ground into fine form and stored in a well-labeled conical flask prior to digestion.

Digestions of sediment and winkles samples: These were done by methods adopted by Wokoma [20] and Onwali et al. [21], for the digestion of each of the sediment and winkles, $1.0 \mathrm{~g}$ of the finely ground sample was heated in a mixture of nitric and perchloric acids in the ratio of 3:2 and refluxed on a hot plate in a fume hood at $110^{\circ} \mathrm{C}$ and allowed to heat for 45 minutes. The resultant solution was filtered and the filtrate made up to $20 \mathrm{ml}$ with deionised water. The digested sample was stored in 
appropriately labeled plastic bottle prior to trace metals analyses.

Digestion of water samples: This was done by method adopted by Davies et al. [19], for each water sample, $100 \mathrm{ml}$ were filtered and acidified with $10 \mathrm{ml} \mathrm{HNO}_{3}$ and $10 \mathrm{ml} 50 \% \mathrm{HCl}$ solutions and evaporated to near dryness. This was transferred to a $100 \mathrm{ml}$ volumetric flask and made up to the mark with deionised water.

Determination of trace metals in water, winkles and sediment: Trace metal levels in water, winkles and sediment were determined using atomic absorption spectroscopy (AAS), model: Varian spectra 100, Australia. Standard solutions of the investigated metals were prepared. The AAS was set with power on for ten minutes. The standard metal solutions were injected to calibrate the AAS using acetylene gas. An aliquot of the digest solutions were injected and the levels of each metal obtained from the AAS.

The quality control of the AAS was guaranteed through the implementation of laboratory quality assurance and laboratory methods, including the use of standard operating procedures, calibrations with standards and analyses with reagent blanks. In addition, samples were

$$
\begin{aligned}
& \operatorname{EXP}_{\text {Ingestion }}=\frac{\mathrm{CW} \times \mathrm{IR} \times \mathrm{EF} \times \mathrm{ED}}{\mathrm{BW} \times \mathrm{AT}} \\
& \mathrm{EXP}_{\text {Dermal }}=\frac{\mathrm{CW} \times \mathrm{SA} \times \mathrm{KP} \times \mathrm{ABS} \mathrm{D} \times \mathrm{ET} \times \mathrm{ED} \times \mathrm{CF}}{\mathrm{BW} \times \mathrm{AT}}
\end{aligned}
$$

analysed in triplicates, all chemicals and reagents used were of analytical grades even as the samples were digested alongside blanks and the sample bottles tightly capped before the analyses.

Health risk assessment: The exposure assessment refers to the determination of the magnitude, frequency, duration and route of exposure with respect to the chemical contaminants in question [26]. In order to assess human health risk of any chemical contaminant, a complete risk assessment procedure, which involves a four-step process, must be followed. The first step which is hazard identification was achieved by measuring the concentrations of trace metals in water, winkles and sediment. The second step which is the exposure assessment for the inhabitant of the area was estimated for two categories (adult and children) and examined through ingestion (water and winkles) and dermal absorption (water) routes based on the USEPA risk assessment methodology [26]. These two pathways were chosen because they are the most significant routes of exposure. The exposure dose for water ingestion and dermal absorption was calculated from Equations 1 and 2 , respectively.

1 2

where $\operatorname{EXP}_{\text {Ingestion }}$ is the exposure dose through ingestion of water $(\mathrm{mg} / \mathrm{kg} /$ day $), \operatorname{EXP}_{\text {Dermal }}$ is the exposure dose through dermal absorption $(\mathrm{mg} / \mathrm{kg} /$ day), CW is concentration of trace metals in water $(\mathrm{mg} / \mathrm{l})$, IR is water ingestion rate (1/day), $\mathrm{EF}$ is the exposure frequency (days/year), ED is exposure duration, BW is the average body weight $(\mathrm{kg})$, AT is the average time (days), SA is the exposed skin area $\left(\mathrm{cm}^{2}\right)$, ET is exposure time (hour/day), CF is the conversion factor $\left(1 / \mathrm{cm}^{3}\right), \mathrm{KP}$ is the dermal permeability coefficient $(\mathrm{cm} /$ hour $)$ and $\mathrm{ABS}_{\mathrm{D}}=$ Dermal absorption factor (no unit).

The exposure dose for winkles' consumption was evaluated by calculating the level of exposure resulting from the consumption of a particular metal in winkles using Equation 3.

where $\mathrm{CC}$ is the concentration of trace metals in winkles tissue $(\mathrm{mg} / \mathrm{kg})$, IR is the ingestion rate, FI is the fraction ingested (no unit), EF is the exposure frequency (days/year), $\mathrm{ED}$ is the exposure duration over a life time, $\mathrm{BW}$ is the body weight and AT is the average life time (70 years $x 365$ days).

Dose - response which is the third process was based on the existing toxicity information developed for different chemical pollutants. It is
$\mathrm{EXP}_{\text {Winkles }}=\frac{\mathrm{CC} \times \mathrm{IR} \times \mathrm{FI} \times \mathrm{EF} \times \mathrm{ED}}{\mathrm{BW} \times \mathrm{AT}} \quad 3$ 
also known as reference dose (RfD). Oral reference dose (RfD) is employed in this study for the metals as suggested by the United Nations Food and Agricultural Organization (FAO) and WHO [27]. The final step, which is the risk characterisation, was carried out by evaluating the non-cancer risk in terms of Hazard quotient (HQ). In order to develop HQ, comparison of the calculated contaminant from each exposure route (ingestion and dermal) with the reference dose was carried out using Equations 4 and 5 respectively [28].

$$
\begin{aligned}
& \mathrm{HQ}_{\text {Ingestion }}=\frac{\mathrm{EXP}_{\text {Ingestion }}}{\mathrm{RfD}_{\text {Ingestion }}} \\
& \mathrm{HQ}_{\text {Dermal }}=\frac{\mathrm{EXP}_{\text {Dermal }}}{\mathrm{RfD}_{\text {Dermal }}}
\end{aligned}
$$

Where, $\mathrm{HQ}_{\text {Ingestion }}$ is the hazard quotient through ingestion and $\mathrm{HQ}_{\text {Dermal }}$ is the hazard quotient through dermal contact, $\mathrm{RfD}_{\text {Ingestion }}$ is the oral reference dose ingestion and $\mathrm{RfD}_{\text {Dermal }}$ is the dermal reference dose $(\mathrm{mg} / \mathrm{kg} /$ day) [29]. HQ for winkles' consumption was determined by expressing it as the ratio of intake of winkles to the oral reference dose (RfD) of the metal of concern according to Equation 6 [30].

$\mathrm{HQ}=\frac{\text { Intake }_{\text {(Winkles) }}}{\text { RfD }}$

6

All exposure assessment parameters for ingestion and dermal absorption of metals in water and ingestion of metals in winkles, used in this study are as provided by USEPA [27], Naveedullah et al. [28], Wu et al. [29], Iqbal and Shah [31] and Ijeoma et al. [32]. The parameters include: $\mathrm{SA}=18,000 \mathrm{~cm}^{2}, \mathrm{KP}$ $(\mathrm{cm} /$ hour $)=(\mathrm{Pb}=1.0 \mathrm{E}-4 ; \mathrm{Ni}=2.0 \mathrm{E}-4 ; \mathrm{Cu}=$ $1.0 \mathrm{E}-3 ; \mathrm{Cr}=1.0 \mathrm{E}-3 ; \mathrm{Cd}=1.0 \mathrm{E}-3 ; \mathrm{As}=1.0 \mathrm{E}-3)$, $\mathrm{ABS}_{\mathrm{D}}$ (no unit) $=0.001$, ET (hour/day) $=0.6$, $\mathrm{EF}($ days/year $)=365, \mathrm{CF}=1 / \mathrm{cm}^{3}, \mathrm{BW}(\mathrm{kg})=$ $70, \mathrm{ED}($ years $)=70, \mathrm{IR}(\mathrm{kg} /$ day $)=0.040, \mathrm{FI}$ (no unit $)=1$ (assuming that the whole muscle fillet of the winkle is consumed), AT (days) $=\mathrm{ED} \times$ $\mathrm{EF}, \mathrm{RfD}_{\text {Ingestion }}(\mathrm{mg} / \mathrm{kg} /$ day $)=(\mathrm{As}=0.0003$; $\mathrm{Cd}=0.01 ; \mathrm{Cu}=0.04 ; \mathrm{Pb}=0.036 ; \mathrm{Cr}=0.03 ; \mathrm{Ni}$
$=0.02 ; \mathrm{Zn}=0.3), \mathrm{RfD}_{\text {Dermal }}(\mathrm{mg} / \mathrm{kg} /$ day $)=(\mathrm{Pb}$ $=5.25 \mathrm{E}-4 ; \mathrm{Ni}=5.4 \mathrm{E}-3 ; \mathrm{Cu}=1.2 \mathrm{E}-2 ; \mathrm{Cr}=6 \mathrm{E}-5$; $\mathrm{Cd}=1 \mathrm{E}-5 ; \mathrm{As}=1.23 \mathrm{E}-4 ; \mathrm{Hg}=2.10 \mathrm{E}-5$ ).

The HQs for each sample were summed up to obtain overall toxic risk, the hazard index (HI) as indicated in the Equation 7.

$$
\mathrm{HI}=\Sigma \mathrm{HQ}_{i}, \quad i=1 \ldots n \quad 7
$$

Where $\mathrm{i}=$ the number of trace metals. If the calculated HI is less than one, then the noncarcinogenic adverse effect due to the exposure pathway or toxicant was assumed to be negligible.

Data analysis: The data generated were subjected to statistical analyses using the Statistical Package for Social Sciences (SPSS) version 20.0 (SPSS Inc., Chicago, USA).

\section{RESULTS AND DISCUSSION}

Concentration levels of trace metals in water, sediment and winkles' samples: Levels of the investigated trace metals $(\mathrm{Cd}, \mathrm{Cr}, \mathrm{Cu}, \mathrm{Pb}$ and $\mathrm{Zn}$ ) in water, sediment and winkles analysed in this study are presented in Tables 1 to 3 , respectively. In Table 1 , the mean levels (mg/l) of the metals in water ranged from 0.016 for $\mathrm{Cr}$ to 0.087 for $\mathrm{Cd}$ in wet season and 0.010 for $\mathrm{Cu}$ to 0.082 for $\mathrm{Zn}$ in dry season. Pb level in the water during the dry season in the two locations was below the detection limit of the AAS. In Table 2, the mean levels $(\mathrm{mg} / \mathrm{kg})$ of the metals in sediment ranged from 0.002 for $\mathrm{Pb}$ to 0.161 for $\mathrm{Zn}$ in the wet season and 0.001 for $\mathrm{Pb}$ to 0.438 for $\mathrm{Cu}$ in the dry season. As presented in Table 3 for the winkles, the mean levels $(\mathrm{mg} / \mathrm{kg}$ ) of the metals in Pachymelania bryonensis, ranged from 0.002 for $\mathrm{Pb}$ to 0.069 for $\mathrm{Cd}$ during the wet season, and 0.001 for $\mathrm{Pb}$ to 0.058 for $\mathrm{Cd}$ during the dry season, while in Pachymelania fusca mutans, the metals levels $(\mathrm{mg} / \mathrm{kg})$ ranged from 0.002 for $\mathrm{Pb}$ to 0.069 for $\mathrm{Cu}$ during the wet season, and 0.001 for $\mathrm{Pb}$ to 0.058 for $\mathrm{Cu}$ during the dry season.

In this study, the levels of the investigated trace metals were generally low in all the samples and were within the permissible limits. However, $\mathrm{Zn}$ was higher in water compared to the winkles and 
sediment. Zn was equally higher in the sediment during the wet season than in the dry season. This could be attributed to excessive run-off during wet season which may have washed wastes laden with $\mathrm{Zn}$ from various sources into the river. $\mathrm{Zn}$ is a co-enzyme for over 200 enzymes involved in immunity, new cells growth and acid-base regulation [33]. Zn levels recorded in water and winkles in this study are comparable to those reported by Aderinola et al. [34] in Lagos Lagoon, Nigeria.

$\mathrm{Cu}$ level in sediment recorded in this study was higher than the value reported by Ekeanyanwu et al. [35] in sediment from Okwumeshi River, Nigeria. $\mathrm{Cu}$ is considered essential for normal growth and reproduction in animals and humans. However, $\mathrm{Cu}$ - related health effects such as renal, cardiovascular, reproductive and immunological have been reported [36]. High levels of metals in sediment could be due to the fact that many of these metals are rapidly removed from water into the underlying sediment [34]. The high level of $\mathrm{Cu}$ in sediment compared with that in water and the winkles recorded in this study is in agreement with the concept that sediment is the sink for a variety of pollutants and that it allows contaminants that escape detection by water analysis to be identified [37, 3].

Table 1: Levels (mg/l) of trace metals in water at Akani Obio Uruan River

\begin{tabular}{clllllll|l}
\hline location & Season & $\mathrm{Cr}$ & $\mathrm{Pb}$ & $\mathrm{Cu}$ & $\mathrm{Zn}$ & $\mathrm{Cd}$ \\
\hline \multirow{2}{*}{2} & Wet & 0.015 & 0.005 & 0.002 & 0.085 & 0.087 \\
& Dry & 0.012 & $\mathrm{BDL}$ & 0.002 & 0.080 & 0.002 \\
& Wet & 0.017 & 0.005 & 0.001 & 0.083 & 0.086 \\
& Dry & 0.010 & BDL & 0.017 & 0.083 & 0.088 \\
& Mean (Wet) & 0.016 & 0.005 & 0.002 & 0.084 & 0.087 \\
& Mean (Dry) & 0.011 & BDL & 0.010 & 0.082 & 0.045
\end{tabular}

$\mathrm{BDL}=$ below the detection limit of the AAS.

Table 2: Levels (mg/kg) of trace metals in sediment at Akani Obio Uruan River

\begin{tabular}{cllllllll}
\hline location & Season & $\mathrm{Cr}$ & $\mathrm{Pb}$ & $\mathrm{Cu}$ & $\mathrm{Zn}$ & $\mathrm{Cd}$ \\
\hline \multirow{4}{*}{2} & wet & 0.140 & 0.001 & 0.602 & 0.161 & 0.382 \\
& Dry & 0.128 & 0.001 & 0.510 & 0.142 & 0.319 \\
& Wet & 0.139 & 0.002 & 0.602 & 0.161 & 0.383 \\
& Dry & 0.147 & 0.001 & 0.365 & 0.138 & 0.321 \\
& Mean (Wet) & 0.140 & 0.002 & 0.602 & 0.161 & 0.383 \\
& Mean (Dry) & 0.138 & 0.001 & 0.438 & 0.140 & 0.320 \\
\hline
\end{tabular}

Table 3: Levels (mg/kg) of trace metals in winkles at Akani Obio Uruan River

\begin{tabular}{c|l|l|l|l|l|l|l|l|l|l|l}
\hline & \multicolumn{9}{|c|}{ Pachymelania bryonensis } & \multicolumn{5}{c}{ Pachymelania fusca mutans } \\
\hline location & Season & $\mathrm{Cr}$ & $\mathrm{Pb}$ & $\mathrm{Cu}$ & $\mathrm{Zn}$ & $\mathrm{Cd}$ & $\mathrm{Cr}$ & $\mathrm{Pb}$ & $\mathrm{Cu}$ & $\mathrm{Zn}$ & $\mathrm{Cd}$ \\
\hline \multirow{4}{*}{1} & Wet & 0.004 & 0.002 & 0.010 & 0.130 & 0.069 & 0.038 & 0.002 & 0.077 & 0.128 & 0.018 \\
& Dry & 0.002 & $\mathrm{BDL}$ & 0.005 & 0.124 & 0.055 & 0.030 & 0.001 & 0.060 & 0.121 & 0.012 \\
& Wet & 0.005 & 0.002 & 0.063 & 0.141 & 0.069 & 0.042 & 0.002 & 0.061 & 0.139 & 0.020 \\
& Dry & 0.003 & 0.001 & 0.057 & 0.136 & 0.061 & 0.035 & 0.001 & 0.056 & 0.132 & 0.013 \\
& Mean (Wet) & 0.005 & 0.002 & 0.037 & 0.136 & 0.069 & 0.040 & 0.002 & 0.069 & 0.134 & 0.019 \\
& Mean (Dry) & 0.003 & 0.001 & 0.031 & 0.130 & 0.058 & 0.033 & 0.001 & 0.058 & 0.127 & 0.013 \\
\hline
\end{tabular}


In rivers, sediment contains high levels of metals than the overlying water [35]. Obviously, the high $\mathrm{Cu}$ level in sediment recorded in this study during the wet season could be attributed to the frequent rainfall that leached $\mathrm{Cu}$ compounds and agricultural wastes from nearby farmlands into the river. However, the $\mathrm{Cu}$ levels for the two seasons recorded in water, sediment and the winkles were all below the recommended international standards.

$\mathrm{Cr}$ level recorded in sediment in this study was higher than the values recorded in water and winkles. The high $\mathrm{Cr}$ level in sediment during the dry season suggests a reduction in the volume of water (dilution) which could lead to an increase in the level of the metal in sediment. On the other hand, the elevated level of $\mathrm{Cr}$ in winkles during the wet season could be attributed to increase in the level of the metal in the water and sediment which could lead to higher absorption by winkles due to increased feeding regime. However, the levels of $\mathrm{Cr}$ in all the samples in this study did not exceed the recommended limits by international and national bodies. $\mathrm{Cr}$ is an essential trace nutrient and a vital component of glucose, but its toxicity damages the liver, lungs and causes haemorrhage in organs [38].

$\mathrm{Pb}$ level in this study was generally low in each of the analysed samples and was below the AAS detectable limit in water during the dry season. $\mathrm{Pb}$ levels in all samples recorded in this study were in agreement with those reported in Qua Iboe River Estuary, Nigeria by Dan et al. [39]. $\mathrm{Pb}$ is a toxic metal which has no metabolic benefits in humans and aquatic biota. It is said to be one of the most toxic trace metals in aquatic system [3]. Indeed the presence of $\mathrm{Pb}$ in any compartment of aquatic ecosystem indicates contamination [40].

Indeed, the levels of trace metals in an aquatic or terrestrial environment and their subsequent accumulation in organisms affect the survival of the organisms in such an environment and hence the need to investigate the toxic index of consumption of such aquatic organisms by humans $[30,3]$.

\section{Estimated exposure to trace metals through} ingestion and dermal absorption: The estimated exposures of humans to trace metals through water ingestion, water absorption (dermal) and winkles' ingestion are presented in Tables 4 to 6 . Table 4 presents the exposure to trace metals through water ingestion. The exposure to the metals through water absorption (dermal) is presented in Table 5 while the exposure to the metals through winkles' ingestion is presented in Table 6 . In all the pathways of exposures, $\mathrm{Zn}$ recorded high exposure while $\mathrm{Pb}$ recorded the least in both adults and children. For water ingestion in Table 4, $\mathrm{Zn}$ exposure was $2.9 \mathrm{E}-3$ in adults and 3.0 E-3 in children while $\mathrm{Pb}$ exposure was $7.2 \mathrm{E}-5$ in adults and 1.2 E-4 in children. For water absorption (dermal) in Table 5, Zn exposure was $3.1 \mathrm{E}-8$ in adults and 5.3 E-8 in children while $\mathrm{Pb}$ exposure was $7.6 \mathrm{E}-10$ in adults and 1.3 E-9 in children. For winkles' ingestion in Table 6, the exposure of $\mathrm{Zn}$ in Pachymelania bryonensis was $4.7 \mathrm{E}-3$ in adults and $8.0 \mathrm{E}-3$ in children while $\mathrm{Pb}$ exposure was 7.2 E-5 in adults and 1.2 E-4 in children. In Pachymelania fusca mutans, $\mathrm{Zn}$ exposure was 4.6 E-3 in adults and 7.8 E-3 in children while $\mathrm{Pb}$ exposure was $7.2 \mathrm{E}-5$ in adults and $1.2 \mathrm{E}-4$ in children.

Table 4: Estimated human exposure to trace metals through water ingestion

\begin{tabular}{ccc}
\hline Metal & Adults & Children \\
\hline $\mathrm{Cr}$ & $6.1 \mathrm{E}-4$ & $1.0 \mathrm{E}-3$ \\
$\mathrm{~Pb}$ & $7.2 \mathrm{E}-5$ & $1.2 \mathrm{E}-4$ \\
$\mathrm{Cu}$ & $1.8 \mathrm{E}-4$ & $3.0 \mathrm{E}-4$ \\
$\mathrm{Zn}$ & $2.9 \mathrm{E}-3$ & $3.0 \mathrm{E}-3$ \\
$\mathrm{Cd}$ & $1.5 \mathrm{E}-3$ & $2.6 \mathrm{E}-3$ \\
\hline
\end{tabular}


Generally, the exposures for all the pathways (oral ingestion and dermal absorption) were higher in children than adults. This is because the body weight of a child is less than that of an adult

Table 5: Estimated exposure to trace metals through water (dermal) absorption

\begin{tabular}{ccc}
\hline Metal & Adults & Children \\
\hline $\mathrm{Cr}$ & $6.4 \mathrm{E}-9$ & $1.1 \mathrm{E}-8$ \\
$\mathrm{~Pb}$ & $7.6 \mathrm{E}-10$ & $1.3 \mathrm{E}-9$ \\
$\mathrm{Cu}$ & $1.9 \mathrm{E}-9$ & $3.2 \mathrm{E}-9$ \\
$\mathrm{Zn}$ & $3.1 \mathrm{E}-8$ & $5.3 \mathrm{E}-8$ \\
$\mathrm{Cd}$ & $1.6 \mathrm{E}-8$ & $2.8 \mathrm{E}-8$
\end{tabular}

According to Li and Zhang [30], $\mathrm{Zn}$ is seen as an essential nutrient for humans and helps in regulating body functions. Exposure to $\mathrm{Zn}$

through oral ingestion of water was high in adults and children due to high level of $\mathrm{Zn}$ in the water.

Table 6: Estimated human exposure to trace metals through winkles' ingestion

\begin{tabular}{ccccc}
\hline & \multicolumn{2}{c}{ Pachymelania bryonensis } & \multicolumn{2}{c}{ Pachymelania fusca mutans } \\
Metal & Adults & Children & Adults & Children \\
\hline $\mathrm{Cr}$ & $1.0 \mathrm{E}-4$ & $1.8 \mathrm{E}-4$ & $1.2 \mathrm{E}-3$ & $2.1 \mathrm{E}-3$ \\
$\mathrm{~Pb}$ & $7.2 \mathrm{E}-5$ & $1.2 \mathrm{E}-4$ & $7.2 \mathrm{E}-5$ & $1.2 \mathrm{E}-4$ \\
$\mathrm{Cu}$ & $1.1 \mathrm{E}-3$ & $2.0 \mathrm{E}-3$ & $2.2 \mathrm{E}-3$ & $3.8 \mathrm{E}-3$ \\
$\mathrm{Zn}$ & $4.7 \mathrm{E}-3$ & $8.0 \mathrm{E}-3$ & $4.6 \mathrm{E}-3$ & $7.8 \mathrm{E}-3$ \\
$\mathrm{Cd}$ & $2.2 \mathrm{E}-3$ & $3.8 \mathrm{E}-3$ & $5.4 \mathrm{E}-4$ & $9.1 \mathrm{E}-4$ \\
\hline
\end{tabular}

The estimated hazard quotients (HQ) of trace metals exposure to humans through the various pathways are presented in Tables 7 to 9 . Table 7 shows the estimated HQ to the metals exposure by oral ingestion of water $\left(\mathrm{HQ}_{\mathrm{o}}\right)$. The estimated HQ of the metals by dermal absorption of water $\left(\mathrm{HQ}_{\mathrm{D}}\right)$ and winkles' ingestion $\left(\mathrm{HQ}_{\mathrm{W}}\right)$ are presented in Table 8 and Table 9, respectively. The estimated HQ of the metals exposure to humans through the various pathways was in the order: $\mathrm{Cd}>\mathrm{Cr}>\mathrm{Pb}>\mathrm{Zn}>\mathrm{Cu}$ for adults and children. Each of the $\mathrm{HQ}_{\mathrm{O}}, \mathrm{HQ}_{\mathrm{D}}$ and $\mathrm{HQ}_{\mathrm{W}}$ was found to be less than unity $(<1)$, indicating that the level of exposure is not likely to cause any obvious adverse effects [41]. These results were in close agreement to those reported by Wu et al. [29] for adults and children from Yangtze River in Nanjing, Song et al. [42] from Yellow River, China and Wang et al. [43]. Accordingly, the HI of each sample was $<1$, implying that noncarcinogenic adverse effect due to each of the exposure pathway is negligible.

Table 7: Hazard quotient of trace metals exposure by oral ingestion of water $\left(\mathrm{HQ}_{\mathrm{o}}\right)$.

\begin{tabular}{ccl}
\hline Metals & $\mathrm{HQ}_{\mathrm{O}}($ Adults $)$ & $\mathrm{HQ}_{\mathrm{O}}($ Children $)$ \\
\hline $\mathrm{Cr}$ & $1.2 \mathrm{E}-3$ & $2.0 \mathrm{E}-3$ \\
$\mathrm{~Pb}$ & $5.1 \mathrm{E}-4$ & $8.5 \mathrm{E}-5$ \\
$\mathrm{Cu}$ & $4.5 \mathrm{E}-6$ & $7.5 \mathrm{E}-6$ \\
$\mathrm{Zn}$ & $9.6 \mathrm{E}-6$ & $1.6 \mathrm{E}-6$ \\
$\mathrm{Cd}$ & $3.0 \mathrm{E}-3$ & $5.2 \mathrm{E}-3$ \\
\hline
\end{tabular}


Table 8: Hazard quotient of trace metals exposure by dermal absorption of water $\left(H Q_{D}\right)$

\begin{tabular}{ccc}
\hline Metals & $\mathrm{HQ}_{\mathrm{D}}$ (Adults) & $\mathrm{HQ}_{\mathrm{D}}($ Children $)$ \\
\hline $\mathrm{Cr}$ & $1.2 \mathrm{E}-11$ & $2.2 \mathrm{E}-11$ \\
$\mathrm{~Pb}$ & $5.4 \mathrm{E}-13$ & $9.2 \mathrm{E}-13$ \\
$\mathrm{Cu}$ & $4.7 \mathrm{E}-14$ & $8.0 \mathrm{E}-14$ \\
$\mathrm{Zn}$ & $1.0 \mathrm{E}-13$ & $1.7 \mathrm{E}-13$ \\
$\mathrm{Cd}$ & $3.2 \mathrm{E}-11$ & $5.6 \mathrm{E}-11$ \\
\hline
\end{tabular}

Table 9: Hazard quotient of trace metals exposure by winkles' ingestion $\left(\mathrm{HQ}_{\mathrm{w}}\right)$

\begin{tabular}{lllll}
\hline \multirow{2}{*}{ Metals } & \multicolumn{2}{l}{ Pachymelania bryonensis } & \multicolumn{2}{l}{ Pachymelania fusca mutans } \\
$\mathrm{Cr}$ & $\mathrm{HQ}_{\mathrm{W}}$ (Adults) & $\mathrm{HQ}$ (Children) & $\mathrm{HQ}$ (Adults) & HQ (Children) \\
$\mathrm{Pb}$ & $2.0 \mathrm{E}-4$ & $3.6 \mathrm{E}-4$ & $2.4 \mathrm{E}-3$ & $4.2 \mathrm{E}-3$ \\
$\mathrm{Cu}$ & $5.1 \mathrm{E}-5$ & $8.5 \mathrm{E}-5$ & $5.1 \mathrm{E}-5$ & $8.5 \mathrm{E}-5$ \\
$\mathrm{Zn}$ & $2.7 \mathrm{E}-5$ & $5.0 \mathrm{E}-5$ & $5.5 \mathrm{E}-5$ & $9.5 \mathrm{E}-5$ \\
$\mathrm{Cd}$ & $1.5 \mathrm{E}-5$ & $2.6 \mathrm{E}-5$ & $1.5 \mathrm{E}-5$ & $2.6 \mathrm{E}-5$ \\
\hline
\end{tabular}

\section{CONCLUSION}

The water, sediment and the winkles (Pachymelania bryonensis and Pachymelania fusca mutans) samples analysed in the Akani Obio Uruan River in the Niger Delta of Nigeria contain variable levels of the investigated trace metals. The estimated exposures of humans to the trace metals through water ingestion (oral), water absorption (dermal) through swimming and winkles' ingestion, each gave hazard quotient (HQ) and hazard index (HI) value of less than one $(<1)$. These indicated no risk, since the levels of contamination in each case are not likely to cause any adverse health effects in humans. Further human health risk assessment of the investigated and other trace metals in other rivers in the Nigeria's Niger Delta is recommended for purpose of monitoring and documentation.

\section{REFERENCES}

1. W. Y. Chen (2017), Environmental externalities of urban river pollution and restoration: A hedonic analysis in Guangzhou (China). Lands and Urban Planning, 157, $170-179$.

2. Z. Li, X. Z. Mao, T. Li and S. Y. Zhang (2016), Estimation of river pollution source using the space-time radial basis collocation method. J. Advanced Water Resource, 88, 68 - 79.

3. E. I. Uwah, E. M. Edem, I. E. Udosen, E. D. Udosen and O. M. Udoidiong (2020), Quantification of pollutant levels in water, sediment and winkles in Akani Obio Uruan River, Nigeria. Science J. Analytical Chem., 8 (2), 45 55.

https://doi:10.11648/j.sjac.20200802.12

4. E. A. Laws (1981), Aquatic pollution, New York: John Wiley and Sons

5. S.T. Matsumoto, R. Janaina, S. M. Mario and A. M. Maria (2005), Evaluation of the genotoxic potential due to the action of an effluent contaminated with chromium, by the comet assay in $\mathrm{CHO}-\mathrm{K} 1$ cultures. Caryologia, 58(1), $40-46$

6. E. J. Inam, I. B. Nwoke, E. D. Udosen and N. Offiong (2019), Ecological risks of phenolic endocrine disrupting compounds in an urban tropical river. Environ. Sci. Pollut. Res., 26 (21), 21589

2159. https://doi.org/10.1007/s11356-01905458-7 
7. E. Inam, N. Offiong, S. P. Yang and J. Essien (2015), Assessment of the occurrence and risks of emerging organic pollutants (EOPs) in Ikpa River Basin freshwater ecosystem, Niger Delta -Nigeria. Bull. Environ. Contam. Toxicol., $95(5), 624-631$. 015-1639-9 https://doi.org/10.1007/s00128-

8. M. Horsfall and A. I. Spiff (2013), Principles of environmental pollution, toxicology and waste management. Port Harcourt Nigeria: Onyoma Research Publications.

9. M. Radojevic and V. N. Bashkin (1999), Practical environmental analysis. Cambridge: Royal Society of Chemistry and Thoma Graham House

10. E. I. Uwah, N. P. Ndahi, F. I and V. O. Ogugbuaja (2011), Heavy metal levels in spinach (Amaranthus caudatus) and lettuce (Lactuca sativa) grown in Maiduguri, Nigeria; J. Environ. Chem. Ecotoxico., 3(10), $264-271$.

11. E. I. Uwah (2017), Levels of Some Trace Metals in Two Leafy Vegetables Grown in Mbiaya Uruan, Akwa Ibom State, Nigeria. Int. J. Innovative Environ. Studies Res. 5(2), 40 - 45.

12. M. Barrie, K. Peake and N. B. Jeffery (2006), Sources of heavy metals and polycyclic aromatic hydrocarbons in urban storm water runoff. Science Total Environ, 359, 145 - 155.

13. J. E. Ukpebor and Nchokwere, C. L (2005), The uses of heavy metal load as an indicator of the suitability of Ikpoba River for domestic and consumption purposes. Chemical and Technol. J., 1, $108-115$.

14. R. Lansdown (1986), Lead intelligence attainment and behavior; In Lansdown $\mathrm{R}$ and Yule, W (eds). The Lead Debate. London - Sedney: Crown Helm.

15. C. G. Ingersol, (1995) Sediment tests: In: Fundamentals of aquatic toxicology, $2^{\text {nd }}$ edition, effects environmental fate, and risk assessment, G.M.R (ed): Taylor $\&$ Francis.
16. E. Yunizar (2014), Analysis of the concentration of heavy metalscadmium, mercury and lead in the flesh of sucker mouth catfish (Pterygoplichthys pardalis)in Ciliwung River, Indonesia. http://www.bioflux.com.ro/aacl. AACL Bioflux, 7(1), 33 - 42.

17. A. B. M. Egborge (1994), Water pollution: biodiversity and chemistry of Warri River. Nigeria: Ben Miller Book Nig. Ltd.

18. W. B. Dambo (1992), Tolerance of the periwinkles Pachymelania aurita (Muller) and Tympanotonus fuscastus (Linne) to Refined oils. Environ. Pollution, 79, $293-296$.

19. O. A. Davies, M. E. Alison and H. S. Uyi (2006), Bioaccumulation of heavy metals in water, sediment and periwinkle (Tympanotonus fuscatus var radula) from Elechi Creek, Niger Delta. Afri. J. Biotechnol., 5(10), 968 - 978.

20. O. A. Wokoma (2014), Bioaccumulation of trace metals in water, sediment and crab (Callinectes) from Sombreiro River, Niger Delta, Nigeria. Internal J. Sci. Technol. Res., 3(12), $295-299$.

21. D. O. Onwali, G. Ajuru, H.Brown and F. B. Amadi (2014), The concentration of lead in periwinkle (Tympanotonus fuscatus) and river sediment in Eagle Island River, Port Harcourt. Nigeria. Amer. J. Environ. Protect. 2(2), 37 - 40.

22. I. I. Udousoro, N. A. Offiong and E. M. Abraham (2018), Bioaccumulation and health risk of trace elements in shellfish and their leachates from two coastal areas of Nigeria, Internal. J. Develop. Sustainty, 7(4), 1474 - 1494.

23. S. A. Osakwe and B. O. Peretiemo Clarke (2013), Evaluation of heavy metals in sediments of River Ethiope, Delta state, Nigeria. IOSR J. Applied Chem., 2(4), 1 - 4 .

24. T. K. Ideriah, S. A. Braide and O. A. Briggs (2006), Distribution of lead and total hydrocarbon in tissue of periwinkle (Tympanotonus fuscatus and Pachymelania aurita) in the upper 
Bonny River. Nig. J. Applied Sci. Environ. Managt., 10(2), 145 - 150.

25. E. D. Udosen (2015), Concepts in Environmental Chemistry. Aniko Global Ventures.

26. USEPA (United State Environmental Protection Agency) (1992), Risk assessment guidance for superfund, vol. 1: Human health evaluation manual (Part A). Interim final office of emergency and remedial response, USEPA Washington, D. C.

27. USEPA (United State Environmental Protection Agency) (2014), Human health evaluation manual. supplemental guidance: Update of standard default exposure factors, USEPA Washington, D. C.

28. M. Z. Naveedullah, Y. Chunna, S. Hui, D. Dechao, S. Chaoferg, L. Liping and C. Yingxu (2014), Concentration and human health risk assessment of selected heavy metals in surface water of the Siling Reservoir watershed in Zhejiang Province, China. Polish J. Environ., 23 (3), 801 - 811.

29. B. Wu, D. Zhao and H. Jia (2009), Preliminary risk assessment of trace Metals Pollution in Surface Water from Yangtze River in Nanjing Section, China. Bull. Environ. Contam. Toxicol, 82, $405-409$.

30. S. Li and Y. Zhang (2011), Risk assessment and seasonal variations of dissolved trace metals in the Upper Han River. China. J. Hazardous materials, 7, $1051-1058$.

31. J. Iqbal and M. Shah (2012), Health risk assessment of metals in surface water from freshwater source lakes, Pakistan. Human Ecol. Risk Assesst., 10, 550 506.

32. F.V. Ijeoma, N. Andrew, W. Clare and M. Gillian (2015), Assessment of physicochemical properties and metal contents of water and sediments of Bodo Creek, Niger Delta, Nigeria. J. Toxicol. Environ. Chem., 97(2), 135 - 144.
33. S. Strachan (2010), Trace element. Current naesthesia Criteria Care, 26, 44-48.

34. O. J. Aderinola, V. Kusemiju, E. O. Clarke, (2011), Trace metal distribution in surface water, sediment and tissues of fresh water cat fish (Clarias gariepinus) from Oke-Ofa Canal, Lagos, Nigeria. Inter. J. Geography and Geology, 1(1), $10-22$.

35. C. R. Ekeanyanwu, C. A. Ogbuinyi and O. F. Etiengjirhevwe (2011), Trace metals distribution in fish tissue, bottom sediments and water from Okuemeshi River in Delta State, Nigeria. Environ. Research J., 5(1), 6- 10.

36. M. A. Addo, G. M. Okley, H. A. Affum, S. Acquah, L. K. Gbadageo and J. K. Senu (2011), Level of some heavy metals in water and sediments of Kpeshie Lagoon, La- Accra. Ghana. Research J. Environ. Earth Science, 3(5), 487 - 497.

37. I. Deffew, J. Mair and H. Guzman (2004), An assessment of metal contamination in mangrove sediment and leaves from Puntamal Bay Pacific Panama. Marine Pollut. Bull., 50 (5), $547-552$

38. ATSDR (Agency for Toxic Substances and Disease Registry) (2000), Toxicological profile for chromium. Department of health and human services.

39. S. F. Dan, U. U. Umoh and V. N. Osabor (2014), Seasonal variation of enrichment and contamination of heavy metals in the surface water of Qua Iboe River Estuary and djoining Creeks, South-South, Nigeria. J. Oceanography and Marine sci., 5 (6), 45 $-54$.

40. Y. Chong, X. Xuan, L. Zhu, J. Wang, Y. Goa, K. Yang, X. Shen, B. Lou (2013), distribution of PAHs in surface water, sediment and soils of Hangzhou city, China. Water Research, 38, 3558 - 3568

41. C. Wang and P. R. Gardinali (2013), Detection and occurrence of microconstituents in reclaimed water used for irrigation - a potentially overlooked source. Anal. Bioanal. Chem. 405(18), 59255935. https://doi.org/10.1007/s00216-013-6799-Z 
42. S. Song, L. Fadong, L. Jing and L. Qiang (2013), Distribution and contamination risk assessment of dissolved trace metals in surface waters in the Yellow River Delta, China. J. Human Ecolog. Risk Assesst., 19, 1514 - 1529
43. X. Wang, T. Sato, X. Baoshan and S. Tao (2005), Health risks of heavy metals to the general public in Tianjin, China via consumption of vegetables and fish. Sci. the Total Environ., 350, 28 - 37 